\title{
Demographic masculinisation with increasing parity and out look of sex preference in Bundelkhand region, India
}

\author{
Shilpi Srivastava $^{1}$, Sanjay Sharma ${ }^{2}$, Sushila Kharkwal ${ }^{2}$, Meenakshi Singh ${ }^{1}$ \\ ${ }^{1}$ Department of Obstetrics \& Gynaecology, KGMU Lucknow, Uttar Pradesh, India \\ ${ }^{2}$ MLB Medical College, Jhansi, Uttar Pradesh, India \\ Received: 03 October 2015 \\ Accepted: 23 November 2015 \\ *Correspondence: \\ Dr. Shilpi Srivastava, \\ E-mail: drshilpi30nov@gmail.com \\ Copyright: $($ ) the author(s), publisher and licensee Medip Academy. This is an open-access article distributed under \\ the terms of the Creative Commons Attribution Non-Commercial License, which permits unrestricted non-commercial \\ use, distribution, and reproduction in any medium, provided the original work is properly cited.
}

\begin{abstract}
Background: The objective of the study was to study status of sex ratio at birth with increasing parity and to study outlook of society toward sex preference.

Methods: This is a retrospective study conducted in department of Obstetrics and Gynecology in M.L.B. medical college Jhansi, India. The data collected from records of January 2014 to December 2014. Data of total number of male and female birth also collected showing sex ratio from year 2011 to 2014 and 200 antenatal women interrogated in privacy for sex preference of unborn.

Results: Sex ratio at birth in year 2014 in Bundelkhand region was 835 female per 1000 male. Sex ratio is in declining trend from year 2011 to 2014. Sex ratio in primipara was 960, which decreased to 900 per thousand in second para, further decreased to 830 and 710 female per thousand male in third and fourth para respectively. Sex preference is maximum in multigravida with previous female baby.

Conclusions: Overall, our results provide clear evidence that the sex ratio at birth is decreasing in Bundelkhand. In spite of all efforts and plans there is decreasing trend of sex ratio year by year. There is decreasing trend of sex ratio with increasing parity. Social outlook toward sex preference is more male sex preference is found in multigravida having previous female baby. Male sex preference also found in primigravida and multigravida having previous male baby but in relatively low percentage.
\end{abstract}

Keywords: Demographic masculinisation, Sex ratio, Prenatal sex selection, Parity, PNDT

\section{INTRODUCTION}

Population of India stood at 1.03 billion on 1 March 2001, having risen $21 \%$ between 1991 and 2001. "What did not rise, but rather declined shockingly, was the sex ratio," says the report.

The sex ratio is defined as the number of female born for every 1,000 male born, is a more accurate and refined indicator of the extent of prenatal sex selection. ${ }^{1}$

Demographic masculinisation is a major problem due to missing women. It is no exaggeration to call it gendericide. In India for instance, discrimination against daughters that results from son preference is manifested by the higher probability of death for girls, in spite of the fact that male infants are biologically more likely to die than female infants. ${ }^{2}$ Boys are more numerous to girls at birth. It is around 105 male per 100 female. Early neonatal mortality is higher in males than female. Sex ratio in India (2013-2014) is 940 females per 1,000 males.

Birth ratio at time of conception is called primary birth ratio. Birth ratio at time of birth is called secondary birth ratio and birth ratio of mature organism is tertiary birth ratio. Sample registration system is more frequently used for sex ratio at birth. These estimates provide results at state and national levels, but not at the district level[3]. Internationally sex ratio is 952 per thousand male. 
Women missing in 2010 were 42687 and gender gap was $7.2 \%$. More than $3 / 4$ girls below 5 year that are missing are unborn girls. Three preconditions of modern sex selection are son preference, sex selection technology and low fertility. Sex composition of children is a determinant of parity progression. The underlying cause of sex preference is cultural pressure, dowry system, violence against female. Increasing son preference in some Asian societies has been attributed to cultural values that may override the effects of small family size and socioeconomic development in promoting greater gender equality among children. ${ }^{6}$

Preference for sex can be measured in two ways. The first is by intention data. This method focuses on respondent's sex preference of future birth. The second method is by examining behaviour data. This approach investigates respondent's fertility behaviour given the sex of existing children. However, for investigating sex preference using this method, behaviour data can only be used for examining progression from at least one to higher parity. Behaviour data cannot be used to look at sex preference of an only or first child, assuming an absence of sex selective abortion. Skewed sex ratio has been observed since 1980 after introduction of USG in field of obstetrics. The government has taken action on strengthening the Pre-Conception \& Pre-Natal Diagnostic Techniques Act (PC \& PNDT Act) as well as creating awareness on the issue through various mechanisms. We, as community of doctors, should participate actively in correcting this imbalance.

\section{METHODS}

It is a retrospective study conducted in department of obstetrics and gynaecology in MLB Medical College Jhansi (India) from January 2014 to December 2014, total number of male and female birth has been calculated from yr 2011 to 2014 to know the trend of sex ratio in Bundelkhand region and data collected for sex ratio in relation to parity from January 2014 to December 2014.

Also 200 antenatal patients were interrogated in privacy for sex preference of new born in privacy to know the social outlook for sex preference. They were also asked about willingness of prenatal diagnosis of sex, awareness toward law against prenatal diagnosis of sex and desire to terminate the foetus according to sex preference.

\section{RESULTS}

Sex ratio is found in decreasing trend from year 2011 to 2014 in spite of various efforts of Government of India (Table 1).

In year January 2014 to December 2014: Sex ratio in primipara is 960 per thousand male. Sex ratio in para-2 is 900 per thousand male. Sex ratio in para-3 is 830 per thousand male. Sex ratio in para- 4 is 710 per thousand male. Sex ratio more than para4 is 690 per thousand male (Table 2).

Out of 200 antenatal women maximum number of women $55 \%$ are primipara. Maximum number of women $(77 \%)$ is $21-30$ year old. $50 \%$ of women have monthly income between Rs 2000-5000 per month. 42\% women have only primary education and $34 \%$ not educated (Table 3).

Multigravida with previous female have maximum sex preference, willingness toward prenatal sex diagnosis and to terminate the female foetus even having awareness about law against it (Table 4).

Table 1: Sex ratio from 2011 to 2014.

\begin{tabular}{|llll|}
\hline S.N. & Year & \multicolumn{2}{c|}{ Sex Ratio } \\
\hline 1 & 2011 & $1140 / 1297$ & $=.878$ \\
\hline 2 & 2012 & $1096 / 1285$ & $=.852$ \\
\hline 3 & 2013 & $1201 / 1420$ & $=.845$ \\
\hline \hline 4 & 2014 & $1270 / 1520$ & $=.835$ \\
\hline
\end{tabular}

Table 1 shows decreasing trend of sex ratio from year 2011 to 2014.

Table 2: Sex ratio in relation to parity.

\begin{tabular}{|lllll|}
\hline Parity & $\begin{array}{l}\text { Total } \\
\text { birth }\end{array}$ & $\begin{array}{l}\text { Female } \\
\text { birth }\end{array}$ & $\begin{array}{l}\text { Male } \\
\text { birth }\end{array}$ & $\begin{array}{c}\text { Sex } \\
\text { ratio }\end{array}$ \\
\hline Primipara & 1104 & 562 & 542 & .96 \\
\hline Para2 & 740 & 388 & 352 & .90 \\
\hline Para3 & 382 & 208 & 174 & .83 \\
\hline Para4 & 244 & 142 & 102 & .71 \\
\hline >para4 & 142 & 84 & 58 & .69 \\
\hline
\end{tabular}

Table 2 shows decreasing sex ratio with increasing parity.

Table 3: Distribution of antenatal women.

\begin{tabular}{|c|c|c|}
\hline \multicolumn{3}{|l|}{ Parity } \\
\hline Primigravida & 110 & $55 \%$ \\
\hline Multigravida (previous male) & 54 & $27 \%$ \\
\hline Multigravida (previous female) & 36 & $18 \%$ \\
\hline \multicolumn{3}{|l|}{ Age } \\
\hline$<20$ year & 20 & $10 \%$ \\
\hline 20-30 year & 154 & $77 \%$ \\
\hline $30-40$ year & 22 & $11 \%$ \\
\hline$>40$ year & 4 & $2 \%$ \\
\hline \multicolumn{3}{|l|}{ Monthly income } \\
\hline$<2000$ & 50 & $25 \%$ \\
\hline $2000-5000$ & 100 & $50 \%$ \\
\hline $5000-10,000$ & 34 & $17 \%$ \\
\hline$>10,000$ & 16 & $8 \%$ \\
\hline \multicolumn{3}{|l|}{ Education } \\
\hline Uneducated & 69 & $34.5 \%$ \\
\hline Primary school & 84 & $42 \%$ \\
\hline Secondary school & 30 & $15 \%$ \\
\hline Graduation & 17 & $8.5 \%$ \\
\hline Post graduation & 0 & \\
\hline
\end{tabular}


Majority of patients, selected randomly from population were uneducated and belonged to lower socioeconomic status.

Table 4: Preference of sex in couples.

\begin{tabular}{|lll|} 
& $\begin{array}{l}\text { Sex preference } \\
\text { Male } \\
\text { female }\end{array}$ & $\begin{array}{l}\text { No Sex } \\
\text { preference }\end{array}$ \\
\hline Primigravida & 48 & $50(45 \%)$ \\
\hline $\begin{array}{l}\text { Multigravida with } \\
\text { previous male } \\
\text { baby }\end{array}$ & 12 & $31(57 \%)$ \\
\hline $\begin{array}{l}\text { Multigravida with } \\
\text { previous female } \\
\text { baby }\end{array}$ & $\begin{array}{l}\text { 30 } \\
\text { Majority of patients having male sex } \\
\text { multigravida with previous female baby. }\end{array}$ & $4(11.11 \%)$ \\
\hline
\end{tabular}

\section{DISCUSSION}

In spite of all efforts, national and international plans, sex ratio is decreasing year by year as appeared in other studies specially in developing countries. The cause may vary from country to country, region to region, religion to religion and according to socioeconomic status \& educational status.

Sex ratio according to Census 2011 is 940 per thousand male.

This study was conducted in Maharani Laxmibai Medical College Jhansi from January 2014 to December 2014.

Total delivery conducted in our hospital in this duration was 2608 . In which sex ratio in primipara is 960 , in para 2 it is 900 , in para 3 it is 870 ,in para 4 it is 700 . This result is supported by study carried out in Mumbai, Nowrosjee Wadia maternity hospital from 2007 to 2012 in which sex ratio was $970,879,784,864,150$ per thousand male in para1, 2,3, 4,>4 respectively. Similar study of sex ratio conducted in Bhopal city from August 2011 to September 2011. Sex ratio is 946 in first birth order, which is declining to $788,731,525$ per thousand male as birth order increasing. ${ }^{5}$

In our study out of 200 antenatal patients maximum patients $(55 \%)$ are primigravida. It may be due to high prevalence of home delivery of multipara by dai and skilled birth attendant. Maximum (77\%) belong to age group 21-30 year and due to high prevalence of illiteracy and low socioeconomic status in Bundelkhand region. Majority of patients $(50 \%)$ that are randomly selected belong to group of monthly income Rs 2000-5000 and majority of patients $(84 \%)$ are educated upto primary education and $34.5 \%$ patients are uneducated.

Out of 110 primigravida patients $45 \%$ patients have no preference to sex, $43 \%$ preferred male sex of unborn only $12 \%$ prefer female sex of newborn. Out of 54 multigravida patients having previous male baby 57\% $(n=31)$ have no sex preference, $29.6 \%$ prefer male sex of unborn and $13.4 \%(n=7)$ prefer female baby. Out of 36 multigravida with previous female only $11.11 \%(\mathrm{n}=4)$ have no sex preference, $83.33 \% \quad(n=30)$ have sex preference toward male and $5.5 \%(\mathrm{n}=2)$ have no sex preference.

This study is also supported by Warada Yugali et al maximum number of sex preference was found in multigravida with previous female baby but no sex preference was found in primigravida. ${ }^{4}$ This discrepancy may be due cultural pressure ,high illiteracy, dowry system ,high number of violence on female in northern India.

In our study more prevalence on male sex preference in primigravida in lower education and low income group in found that is not supported by study of Warada Yugali et al. In study of Toppo M, Diwakar et al literacy wise sex ratio shows that education of women empower them to decision making and were engaged in this activity, graduated and post graduated have low sex ratio compare to illiterate and primary school. ${ }^{4,5}$

\section{CONCLUSIONS}

Overall, our results provide clear evidence that the sex ratio at birth is decreasing in Bundelkhand. In spite of all efforts and plans there is decreasing trend of sex ratio year by year. There is decreasing trend of sex ratio with increasing parity. Social outlook toward sex preference is more male sex preference is found in multigravida having previous female baby. Male sex preference also found in primigravida and multigravida having previous male baby but in relatively low percentage.

The underlying cause of low sex ratios at birth is a strong preference for sons. These societies share a patrilineal, patrilocal and patriarchal kinship system, in which sons hold a higher status and have more value to their parents than daughters.

\section{Funding: No funding sources}

Conflict of interest: None declared

Ethical approval: The study was approved by the Institutional Ethics Committee

\section{REFERENCES}

1. Coney NS, Mackey WC. The woman as final arbiter: a case for the facultative character of the human sex ratio. J Sex Res. 1998;35(2):169-7.

2. Das Gupta M. "Gender Bias in China, South Korea and India 1920-1990", Development and Change. 1999;30:619-52.

3. United Nation's population funds: India (Internet). 2011.trend in sex ratio at birth and estimate of girls missing at birth in India (2001-2008). http://www.unfpa.org 
4. Warade Yugali, Balsarkar Geetha, Bandekar Pooja. A study to review sex ratio at birth and analyze preference for the sex of the unborn. Journal of Obstetrics and Gynaecology of India. 2014;64(1):234.

5. Toppo M, Diwakar A, Pal DK .A study of sex ratio in relation to birth order in Bhopal city. Healthline 2012;3(1):46-9.
6. Croll E. 2000, Endangered Daughters. Discrimination and Development in Asia, London, Routledge.

Cite this article as: Srivastava $S$, Sharma $S$, Kharkwal S, Singh M. Demographic masculinisation with increasing parity and out look of sex preference in Bundelkhand region, India. Int J Reprod Contracept Obstet Gynecol 2015;4:1993-6. 